\title{
Comparative Analysis of the Importance of the Requirements of Passengers and Evaluating the Quality of Air and Bus Transport
}

\author{
Vladimír Konečný ${ }^{1, *}$, Róbert Berežný ${ }^{1}$, Mária Kostolná ${ }^{1}$, and Pavel Šaradín ${ }^{2}$ \\ ${ }^{1}$ University of Žilina, Faculty of Operation and Economics of Transport and Communications, \\ Department of Road and Urban Transport, Univerzitná 1, 01026 Žilina, Slovak Republic \\ ${ }^{2}$ College of Logistics o.p.s.., Palackého 1381/25, 75002 Přerov, Czech Republic
}

\begin{abstract}
The paper deals with the comparison of the importance of passengers' requirements for the quality of the services provided and the quality assessment of air and bus transport. Individual quality criteria and their importance from the point of view of passengers vary depending on the mode of transport. It is also possible to observe the differing importance of quality criteria in relation to groups of passengers. The paper is processed comparison of the importance of individual quality criteria in air and bus services to the research in this area. In the paper is processed IPA matrix for air and bus transport. These are simple matrices that serve to highlight and understand important customer requirements.
\end{abstract}

\section{Introduction}

Quality is the extent to which set of custom characteristics meets the requirements that represent needs and expectations that are identified or predicted and are required. It has become an integral part of our life. It is reflected not only in products and services, but also in the quality of people and the overall quality of life. It is a phenomenon that occurs in everything that only has a bit of a competitive struggle.

Quality is now increasingly important in the field of transport. The exception is not air and bus transport. Quality of service is also one of the most important factors influencing demand for transport. Transport service operations managers need to constantly prioritize resource allocation in order to improve service quality and customer satisfaction [1-3].

According to $[4,5]$ are just some who have pointed to the quality of services as the factor with the strongest impact on demand for bus transport.

The airline industry plays an important role in the service sector itself, as well as contributes significantly to other industries through the ability to transport passengers to their required locations all over the globe [6-8]. It is suggested that probably the three fundamental factors that affect passenger demand in the airline industry are income, fares and service levels. The service quality of the airline companies have affected the goodwill and consumer satisfaction of the companies and have determined the key factors of their

* Corresponding author: vladimir.konecny@fpedas.uniza.sk 
operating costs and profitability. Service quality is usually regarded as the customer's impression of the relative inferiority/superiority of a service provider and its services [9] to its competing alternative, and is often considered similar to the customer's overall attitude towards the company [9].

The issue of quality in bus transport is dealt with under the conditions of the Slovak Republic by Act no. 56/2012 Coll. on road transport and Regulation (EC) No 1370/2007 of the European Parliament and of the Council on public passenger transport services by rail and by road (adopted by European law). Also in the sphere of public transport quality two European standards in the form of Slovak technical standards are binding in the Slovak Republic: (STN EN 13816 and STN EN 15140). Standard STN EN 13816 applies to air passenger, rail, bus and waterborne service providers. It does not exclude vehicles for individual car traffic in the area of taxis. [10] in their studies on measuring and assessing quality in regional rail transport, are based on STN EN 13816.

STN EN 13816 -Transportation. Logistics and services. Public passenger transport. Service quality definition, targeting and measurement. This European Standard specifies the requirements to define, target and measure quality of service in public passenger transport and provides guidance for the selection of related measurement methods. The quality system can be described with the service quality loop which evaluates the delivered service from the customer view as well as from service operator view. The services are determined by the quality loop (Fig. 1). The standard defines a set of eight quality criteria for public passenger transport- availability, accessibility, information, time, customer care, comfort, security, environmental impact.

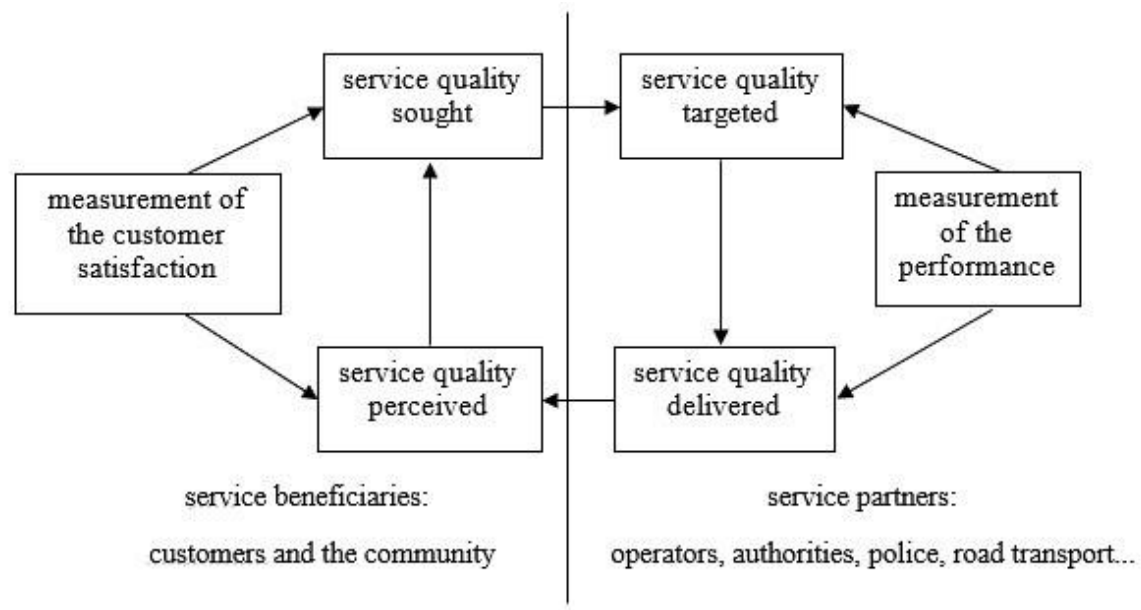

Fig. 1. Service quality loop. Source: elaborated by authors on the basis of standard STN EN 13816

Individual quality criteria and their importance from the point of view of passengers vary depending on the mode of transport. It is also possible to observe the different importance of quality criteria in dependence on groups of passengers, as confirmed by the research [11].

\section{Identification of the most important quality criteria}

\subsection{Identification of the most important quality criteria in bus transport}

The research is based on requirements of standard STN EN 13816, the analysis of contract of services in public interest in SR and of different systems' experience. 
On this basis, the questionnaire was created to find out the most important quality criteria for a customer as well as the importance attached to each criterion. The Likert scale was used in this questionnaire and transformed to points (1- the least important, 5- the most important).

A research of passengers' requirements on service quality was carried out in the autumn in 2016. A representative sample consisted of 629 passengers. The most mentioned quality criteria (with their importance) are shown in the Table 1.

Table 1. Selected passenger requirements (expectations) for the quality of bus transport. Source: elaborated by authors on the basis of own research

\begin{tabular}{|c|l|c|c|}
\hline \multicolumn{3}{|c|}{ Bus Transport } \\
\hline Rank & \multicolumn{1}{|c|}{ Quality Criterion } & Values & $\begin{array}{c}\text { Percentage } \\
\text { Values (\%) }\end{array}$ \\
\hline 1. & Punctuality & 4.50 & 90.0 \\
\hline 2. & Information board on bus & 4.36 & 87.2 \\
\hline 3. & Linking links & 4.26 & 85.2 \\
\hline 4. & Shelter at the bus stop & 4.26 & 85.2 \\
\hline 5. & Availability of timetable & 4.24 & 84.8 \\
\hline 6. & The behaviour of the driver & 4.21 & 84.2 \\
\hline 7. & Driving technique of the driver & 4.13 & 82.6 \\
\hline 8. & Cleanliness of bus stops & 4.02 & 80.4 \\
\hline 9. & Internal cleanliness of the bus & 3.97 & 79.4 \\
\hline 10. & Informations of bus stops & 3.95 & 79.0 \\
\hline 11. & Seats at the bus stop & 3.90 & 78.0 \\
\hline 12. & Sitting on the bus & 3.85 & 77.0 \\
\hline 13. & Possibility of transfers & 3.75 & 75.0 \\
\hline 14. & The impact of the buses on the environment & 3.75 & 75.0 \\
\hline 15. & Safety & 3.63 & 72.6 \\
\hline
\end{tabular}

\subsection{Identification of the most important quality criteria in air transport}

The research is based on study [12]. The study is focused on study the service quality of airline companies, therefore, the passengers boarding the international airline flights of the two domestic airline companies are selected as the research targets.

The questionnaires explain the definitions of the various criteria and use the pair comparison method to request respondents to fill in the degree of influence of some criteria on the other criteria (five types of linguistic variables) as "no influence", "slight influence", "influence", "large influence" and "direct influence". The implementers show the degree of mutual influence based on the size of the numbers.

There were two periods of sampling time provided by the researchers (February 1, 2010 - March 31, 2010 and March 1, 2010 - April 30, 2010). A total of 145 effective samples were retrieved and the effective retrieval rate was $32.2 \%$. The most mentioned quality criteria (with their importance) are shown in the table 2. 
Table 2. Selected passenger requirements (expectations) for the quality of air transport. Source: elaborated by authors on the basis of [12]

\begin{tabular}{|c|l|c|c|}
\hline \multicolumn{3}{|c|}{ Air Transport } \\
\hline Rank & \multicolumn{1}{|c|}{ Quality Criterion } & Values & $\begin{array}{c}\text { Percentage } \\
\text { Values (\%) }\end{array}$ \\
\hline 1. & Truly providing committed services & 9.9101 & 99.10 \\
\hline 2. & Professional training of flight attendants & 9.8529 & 98.53 \\
\hline 3. & Accuracy of various operations & 9.5440 & 95.44 \\
\hline 4. & $\begin{array}{l}\text { Flight attendants are able to initiatively take care of } \\
\text { passenger needs }\end{array}$ & 9.5408 & 95.41 \\
\hline 5. & Initiatively providing the needs of passengers & 9.3859 & 93.86 \\
\hline 6. & Active and rapid response to passenger needs & 9.3392 & 93.39 \\
\hline 7. & Handling of passenger complaints & 9.0684 & 90.68 \\
\hline 8. & Seat (designation) and easy booking processes & 8.1293 & 81.29 \\
\hline 9. & $\begin{array}{l}\text { Service attitude of check-in attendant (ticket } \\
\text { reservations and sale) }\end{array}$ & 8.1242 & 81.24 \\
\hline 10. & Convenience of baggage checkin and check-out & 7.8589 & 78.59 \\
\hline 11. & Internal decorations and cleanliness of flight cabins & 7.4898 & 74.90 \\
\hline 12. & Comfortable seats in the cabins & 7.4327 & 74.33 \\
\hline 13. & Rational ticket prices & 7.4320 & 74.32 \\
\hline 14. & On-time flights & 7.3584 & 73.58 \\
\hline 15. & Provision of flight meals & 7.0472 & 70.47 \\
\hline 16. & Flight safety & 6.9265 & 69.27 \\
\hline 17. & $\begin{array}{l}\text { Books, newspapers and entertainment programs on the } \\
\text { flight }\end{array}$ & 6.5349 & 65.35 \\
\hline 18. & Arrangement of flight time & 6.5264 & 65.26 \\
\hline 19. & Apparel and appearance of the flight attendants & 5.9639 & 59.64 \\
\hline
\end{tabular}

\section{Importance-performance analysis (IPA)}

Importance-Performance Analysis (IPA) has been widely adopted in a variety of business sectors for understanding customer satisfaction, identifying areas for improvement, and prioritizing resource allocation [13-16].

In a conventional IPA [17-19], data are collected from customer surveys that measure customer perceptions of the importance of a list of several product and/or service attributes, and their satisfaction with respect to each of the attributes. The data are then presented in a matrix, with the $\mathrm{x}$-axis depicts attribute importance and the $\mathrm{y}$-axis attribute satisfaction, i.e. performance, with four quadrants based on their rankings (see Fig. 2).

Attributes located in Quadrant 1 are "high importance and low performance", which require managers to "concentrate" their efforts and resources; Quadrant 2 is for attributes that have both high importance and performance rankings, thus managers need to "keep up the good work"; attributes in Quadrant 3 are low in both importance and performance rankings, which are "low priority" for resource allocation, finally those fall into Quadrant 4 are low in importance but high in performance, thus possibly 'overkill', managers might direct their resources elsewhere, particularly to improve the performance of attributes in Quadrant 1. 


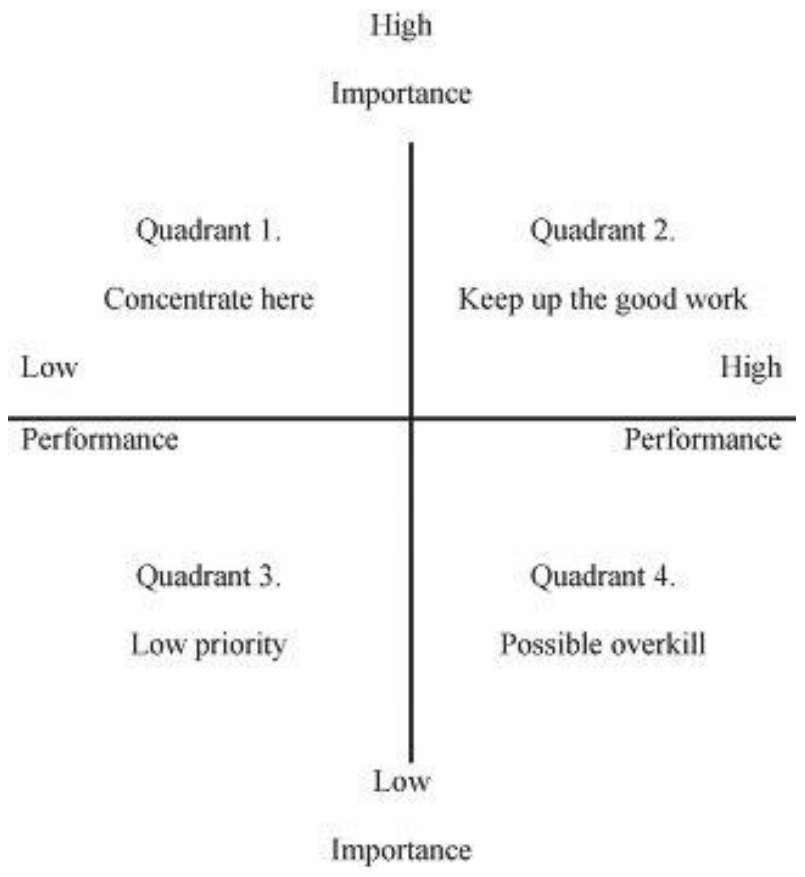

Fig. 2. The Importance-Performance Analysis (IPA) matrix. Source: [8]

The IPA matrix can be supplemented by the numerical value of the so called I-P Total Index with the ability to calculate for any set of quality aspects for which it is know the value of their importance level and the measurement of the quality. I-P Total Index is calculated using the relationship (1). The index can reach values from 0 to 1 .

$$
I-P \text { Total Index }=\frac{\sum_{i=1}^{n} \frac{I_{i}}{100} \cdot \frac{P_{i}}{100}}{\sum_{i=1}^{n} n_{i}}(-)
$$

Where:

$I$ is the importance of the quality aspect in percentage,

$P$ is level of aspect of quality determined by measuring the quality in percentage,

$n$ is the total number of quality aspects.

\subsection{How to build the Importance-Performance Analysis (IPA) matrix}

Step 1: List the variations of the output (Y) along the top of the nut. These outputs are those that the team and / or customer considers important. They can be a subset of the list $\mathrm{Y}$ identified in the process map.

Step 2: Scoring the outputs numerically using any scale (option 1 - 100). The most important output will get the highest number.

Step 3: Identify all potential inputs or causes (X) that may affect the $\mathrm{Y}$ variation and write down the list along the left side of the matrix.

Step 4: Numerical evaluation of the effects of each $\mathrm{X}$ on each $\mathrm{Y}$ is within the matrix body. The evaluation is based on the experience of the team. 


\subsection{Application of the Importance-Performance Analysis (IPA) matrix for air and bus transport}

Table 3 shows percentages values of importance and performance individual quality criteria needed for processing Importance-Performance Analysis (IPA) matrix.

Table 3. Percentages values of importance and performance needed for processing ImportancePerformance Analysis (IPA) matrix. Source: elaborated by authors on the basis of own research in bus transport and in air transport according to data from [8]

\begin{tabular}{|c|c|c|c|c|c|c|c|}
\hline \multicolumn{4}{|c|}{ Air transport } & \multicolumn{4}{c|}{ Bus transport } \\
\hline \multicolumn{2}{|c|}{$\begin{array}{c}\text { Quality } \\
\text { Criterion }\end{array}$} & $\begin{array}{c}\text { Importanc } \\
\text { e (\%) }\end{array}$ & $\begin{array}{c}\text { Performan } \\
\text { ce (\%) }\end{array}$ & \multicolumn{2}{|c|}{$\begin{array}{c}\text { Quality } \\
\text { Criterion }\end{array}$} & $\begin{array}{c}\text { Importan } \\
\text { ce (\%) }\end{array}$ & $\begin{array}{c}\text { Performan } \\
\text { ce (\%) }\end{array}$ \\
\hline A & Punctuality & 73.6 & 69.8 & A & Punctuality & 83.8 & 65 \\
\hline B & Safety & 69.3 & 78.6 & B & Safety & 75.8 & 79 \\
\hline C & $\begin{array}{c}\text { Aircraft } \\
\text { comfort }\end{array}$ & 74.3 & 70.2 & C & $\begin{array}{c}\text { In vehicle } \\
\text { comfort }\end{array}$ & 71.6 & 84 \\
\hline D & $\begin{array}{c}\text { In-flight } \\
\text { service }\end{array}$ & 99.1 & 72.2 & D & $\begin{array}{c}\text { Behaviour } \\
\text { of driver }\end{array}$ & 76.8 & 88 \\
\hline E & $\begin{array}{c}\text { In-flight } \\
\text { food }\end{array}$ & 70.5 & 65.2 & E & $\begin{array}{c}\text { Informatio } \\
\text { n }\end{array}$ & 79.4 & 77 \\
\hline F & Ticket price & 74.3 & 65.6 & F & Cleanliness & 75.8 & 82 \\
\hline
\end{tabular}

IPA matrix was created based on research on the values of selected quality aspects and on the basis of available studies of their importance and measured quality in air and bus transport. All aspects are found in the 2nd quadrant of the IPA matrix which is a positive and desirable state.

IPA matrix are complemented by an I-P Total Index. I-P Total index reaches 0.540 for air transport and 0.609 for bus transport.

I-P Total index $=0,540$

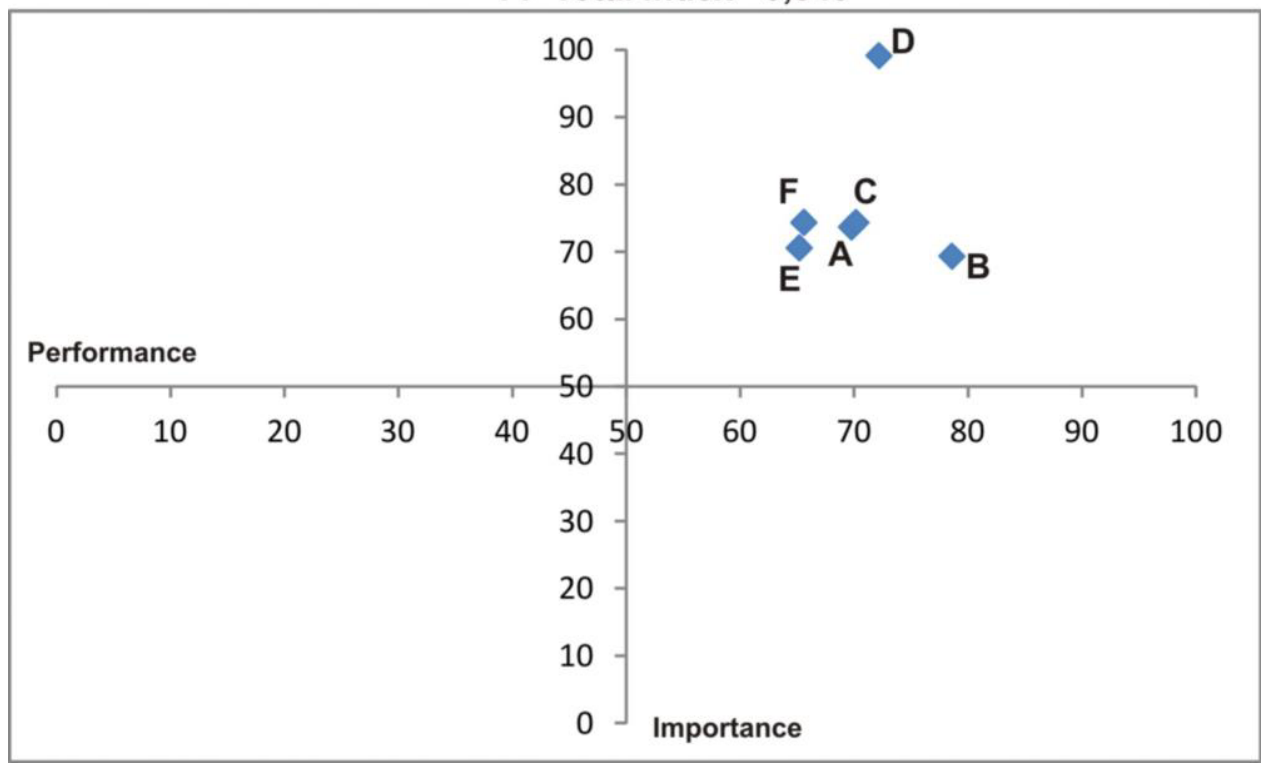

Fig. 3. IPA matrix for air transport. Source: elaborated by authors 
I-P Total Index $=0,609$

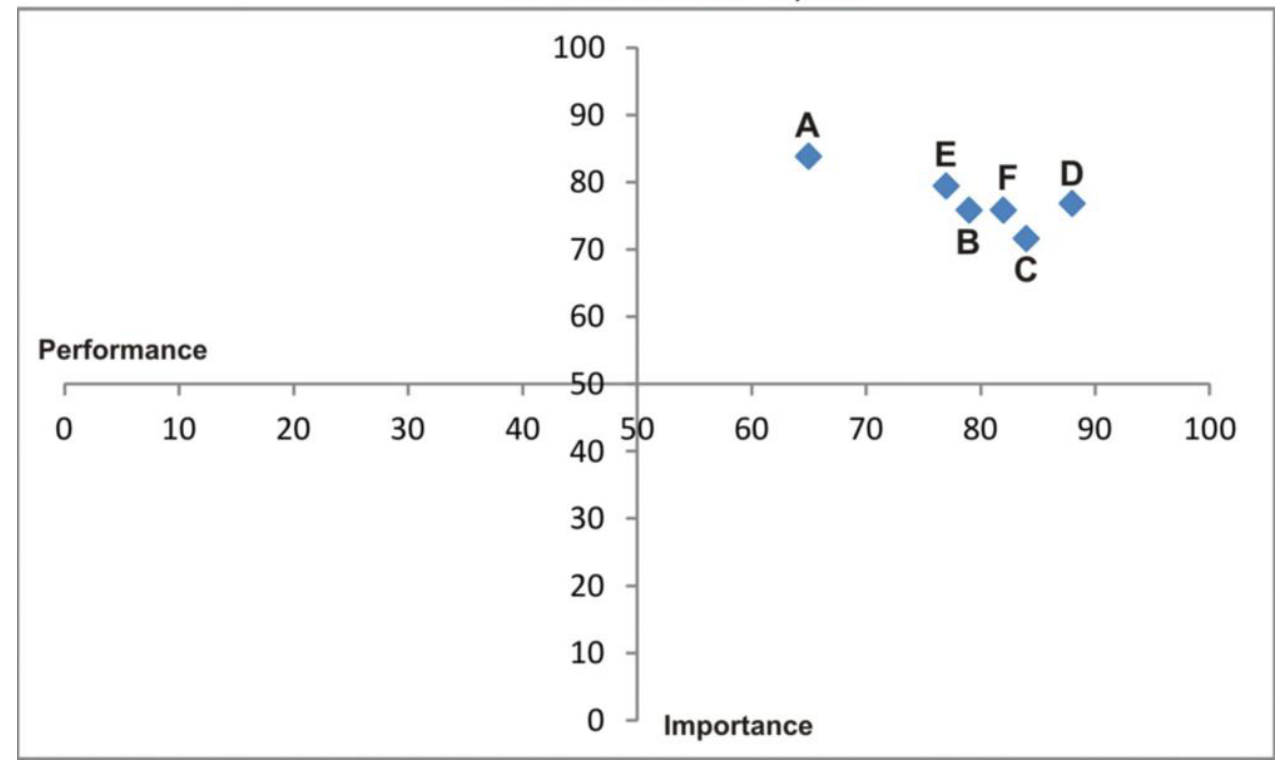

Fig. 4. IPA matrix for bus transport. Source: elaborated by authors

\section{Conclusion}

In order to make the IPA matrix more complex it will be necessary to expand the set of quality aspects in the future. The IPA matrix is a suitable visual and graphical tool for assessing two quality loop dimensions: expected quality and actually measured quality. The IPA matrix allows to compare quality aspects across multiple modes. It is also possible to compare the quality level for different time periods. IPA matrix can be used as a tool for comparing different transport systems or suppliers of services at national and international levels.

The goal should be to position as many points of the IPA matrix with a high importance value into Quadrant 2.

In the case of change the number of quality aspects it is possible to use the I-P Total Index for an objective assessment of quality development. I-P Total index is calculated based on the Importance and Performance values of all aspects of quality.

Future research in this area we would like to focus on the matrix integrating and expressing the relationship between expectations and the level of passenger satisfaction. It would be a transformation of the whole quality loop according to standard EN 13816.

This paper has been developed under support of project: MŠVVŠ SR VEGA No. 1/0566/18 KONEČNÝ, V.: Research on the impact of supply and quality of transport services on the competitiveness and sustainability of demand for public transport.

\section{References}

1. E. Celik, O.N. Bilisik, M. Erdogan, A.T. Gumus, H. Baracli, Transport. Res. Part E: Logist. Transport. Rev. 58 (Supplement C), pp. 28-51 (2013)

2. L. Eboli, G. Mazzulla, Transportation planning and technology, 31, 5, pp.509-523 (2008) 
3. M.W.E. Gonçalves, M. Caetano, J. Airl. Airport Manage. 7, 1, pp. 65-79 (2017)

4. R. Balcombe, R. Mackett, N. Paulley, J. Preston, J. Shires, H. Titheridge, M. Wardman, P. White, TRL Report TRL593 (2004)

5. G. Bresson, J. Dargay, J.L. Madre, A. Pirotte, Transportation Research A, 37, 7, pp. 605-627 (2003)

6. L. Rhoades, B. Waguespack, Managing Service Quality: An International Journal, 18, 1, pp.20-33 (2008)

7. M.S. Kuo, Transport. Res. Part E: Logist. Transport. Rev. 47, 6, pp. 1177-1193 (2011)

8. Z. Lin, I. Vlachos, Transportation Research Part E: Logistics and Transportation Review, 114, pp. 185-195 (2018)

9. A. Parasuraman, V. Zeithmal, L.L. Berry, A. Servqual, Journal of Retailing, 64, 1, pp. 12-40 (1988)

10. J. Gašparík, O. Stopka, L. Pečený, Nase More, 62, pp. 114-118 (2015)

11. R. Kampf, J. Lizbetin, L. Lizbetinova, Communications, 14, 4, pp. 106-108 (2012)

12. R. Wang, H. Shu-Li, H.S. Lin, M.L. Tseng, Procedia - Social and Behavioral Sciences, 25, pp. 419-437 (2011)

13. A. Arbore, B. Busacca, J. Serv. Manage. 22, 3, pp. 409-429 (2011)

14. X. Geng, X. Chu, Expert Syst. Appl. 39, 1, pp. 1492-1502 (2012)

15. L. Bartuska, V. Biba, R. Kampf. Proceedings of the Third International Conference on Traffic and Transport Engineering (Scientific Research Center Ltd. Belgrade, 2016)

16. Y.F. Kuo, J.Y. Chen, W.J. Deng. Total Qual. Manage. Bus. Excel. 23, 7-8, pp. 731748 (2012)

17. J.A. Martilla, J.C. James, J. Market. 41, 1, pp. 77-79 (1977)

18. A.Stelzer, F. Englert, S. Hörold, C. Mayas, Transport. Res. Part E: Logist. Transport. Rev. 89, pp. 259-271 (2016)

19. A.B. Steven, Y. Dong, M. Dresner, Transport. Res. Part E: Logist. Transport. Rev. 48, 4, pp. 743-754 (2012) 